\title{
Need of life cycle thinking for effective utilisation of resources based on developed and developing countries: a scenario for future generation
}

\author{
Mahath Chandran Sherli ${ }^{1}$ - Mophin Kani ${ }^{2}$ \\ Received: 22 September 2017 / Accepted: 23 January 2018 / Published online: 3 February 2018 \\ (C) Springer-Verlag GmbH Germany, part of Springer Nature 2018
}

\section{Introduction}

Sustainable development has gained prominence nowadays due to growing population, affluence and technological advancements in both developed as well as developing countries. Developing countries focus mainly on GDP rather than sustainability, but it is important to consider the natural resources due to the instability of GDP and unscientific rapid steps towards development in the developing countries will lead to various environmental efficiency problems. Moreover, the lack of funding agencies for developing Life Cycle Inventory (LCI) databases is a major problem in most of the developing countries. Development based on meeting the needs of present generations without conceding the capacity of future generations to meet their own needs is sustainable development, as per Brundtland Commission report (Burtland 1987). In the business, community sustainability is coined "the triple bottom line", expressing that industry should expand the traditional economic aspects to include environmental and social dimensions - to create a more "sustainable business" (Elkington 1997). A life cycle of a product (cradle to grave) begins with production of raw materials and extends to manufacture, use, transport and waste management. The life cycle thinking helps reduce the environmental load and thereby promoting sustainable development by preserving and conserving the existing resources for the future generation.

Responsible editor: Philippe Garrigues

Mahath Chandran Sherli malayambt@gmail.com

1 Environmental Engineering \& Management, Department of Civil Engineering, UKF College of Engineering \& Technology, Kollam, Kerala 691302, India

2 Department of Civil Engineering, UKF College of Engineering \& Technology, Kollam, Kerala 691302, India

\section{Discussions}

The world population is drastically increasing at around 10 billion and the affluence is approximately 2 to $4 \%$ at around $8 \%$ GDP growth. If the technology remains static energy use and this situation continues, as according the IPAT conceptual equation attributed to Ehrlich and Holdren (1971), the environmental impact will increase by 10 times in 50 years. The magnitude of this challenge was to reduce the impact by a factor of 10 to support 10 billion people for a better standard of living. Developed countries had already gained importance to sustainable development when compared to developing countries. In developed countries, various LCI databases and Life Cycle Assessment (LCA) methods are available to carry out life cycle assessment studies. Databases like ecoinvent are developing databases for non-OECD countries to support LCA studies. Most of the databases are from western European and USA databases. Municipal solid waste management becomes an important problem for urban authorities. In developing countries, health care waste contributes a major hazardous fraction and thereby redoubling the problems associated with such kind of waste. LCA now becomes a popular tool for estimation and evaluation of impacts related to health and environment from municipal solid waste treatment and disposal programme.

Ohidul Alam's "LCA problems and prospects in Bangladesh" case study associated with healthcare waste management in Chittagong Metropolitan City discloses that conducting a preliminary LCA study based on current scenarios is difficult in developing countries like Bangladesh. The difficulties are due to dissimilarity and defective implementation of law among different authorities, lack of database, their unwillingness to share due to lack of records, etc. (Ohidul Alam 2016). Life cycle assessment needs data and database development approaches. The accuracy of calculations based on LCA depends on the database's quality and the quality of databases is a critical challenge for meaningful decision making. The datasets are available globally, and based on those, 
hundreds of life cycle studies are also generating. But, there is no attention towards creating the datasets for national/regional/local geographical locations due to various reasons like due to lack of knowledge, transparency and expertise. Proper planning, creation, management, maintenance of LCI database, reuse of dataset and interoperability were required especially for developing nations. Smart city development has gained prominence in recent years denoting ideal, future-fit city image where everyone wants to live. But, understanding the key features of a smart city is important because it should fulfil the competitiveness, sustainability and quality of life (Archana and Sohini 2015).

\section{Energy requirements}

The energy requirement for all economic activity is increasing day by day (world-developed as well as developing countries). In Fig. 1, oil and gas demand falls substantially under the blue map scenario and coal demand increased in the BLUE map 2050 scenario. Figure 2 describes the BLUE map scenario of significant additional reductions in final energy intensity above those already implicit in the baseline scenario which occurs across all regions. In Fig. 3, the mix of $\mathrm{CO}_{2}$ abatement options needed to realise the BLUE map scenario varies between countries and regions (Energy technology perspectives (IEA) 2010). The energy demand is increasing at significant rates in response to social and economic development in developing economies. Developmental growth varies between different regions but there are many existing areas where there is energy poverty. Existing energy systems are insufficient, and therefore, there are many challenges to meet the energy demands in developed as well as in developing economies. Developing countries may have the opportunity to make primary technological leaps to the enactment of smart grids, without going through the extensive development of traditional grids. Chemicals, iron and steel, cement, pulp and paper, aluminum and $\mathrm{CO}_{2}$ potential emissions can be saved by using the best available technologies that is to be adopted in developing countries. Engineers are working continuously to improve the energy required per unit of economic output in both developed and developing economies. As a result, it reduces the use of natural resources, environmental impacts and cost. Life Cycle approaches (Table 1) help identify the hot spots and rectify the environmental impacts up to a standard level.

\section{Material use}

The consumption of major materials in developed and developing countries include non-renewable, metals, minerals and fossil fuel-derived products. This leads to habitat destruction, biodiversity loss, stressed fisheries and desertification. The per capita materials usage is tremendously increasing day by day and it depends on the extraction techniques adopted by the people and the usage of a full range of materials that come from and return to Mother Earth. Estimates have shown that between 2000 and 2050 (Fig. 4) (UNEP Reports 2016), the population rises nearly $50 \%$, global energy and material use will grow up to $300 \%$ and economic activity up to $500 \%$. Modern energy services helped a lot in West Asian countries as this will be reflected in biomass consumption. Difficulty in accessing modern energy services is a serious interference to economic as well as to social development. For example, in the case of Africa having high biomass potential, the biomass consumption is more when compared to that of other countries. Access to modern energy services is defined here as household access to electricity and clean cooking facilities (i.e. clean cooking fuels and stoves, advanced biomass cook stoves and biogas systems) (Energy technology perspectives (IEA) 2010). The environmental pressures will increase rapidly if economic growth is coupled with waste generation and resource usage. The trend in global material consumption and environmental impact is increasing day by day due to deforestation as it is increasing approximately one acre per second. About $50 \%$ of the world's tropical and temperate forests are being lost. Seventy-five per cent of marine fisheries are now fished or overfished to capacity. Freshwater withdrawals have doubled between 1960 and 2000 and the rivers including the
Fig. 1 Primary energy demand by fuel and by scenario. Source: Energy technology perspectives (IAE) (2010)

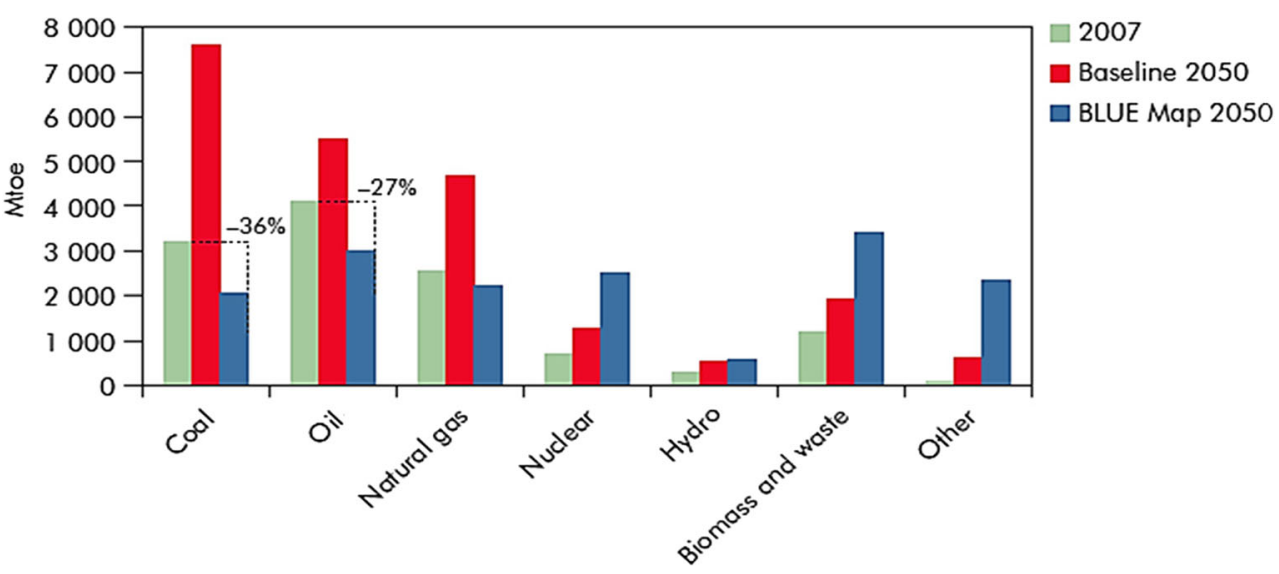


Fig. 2 Historical and projected changes in final energy consumption per unit of GDP. Source: Energy technology perspectives (IAE) (2010)

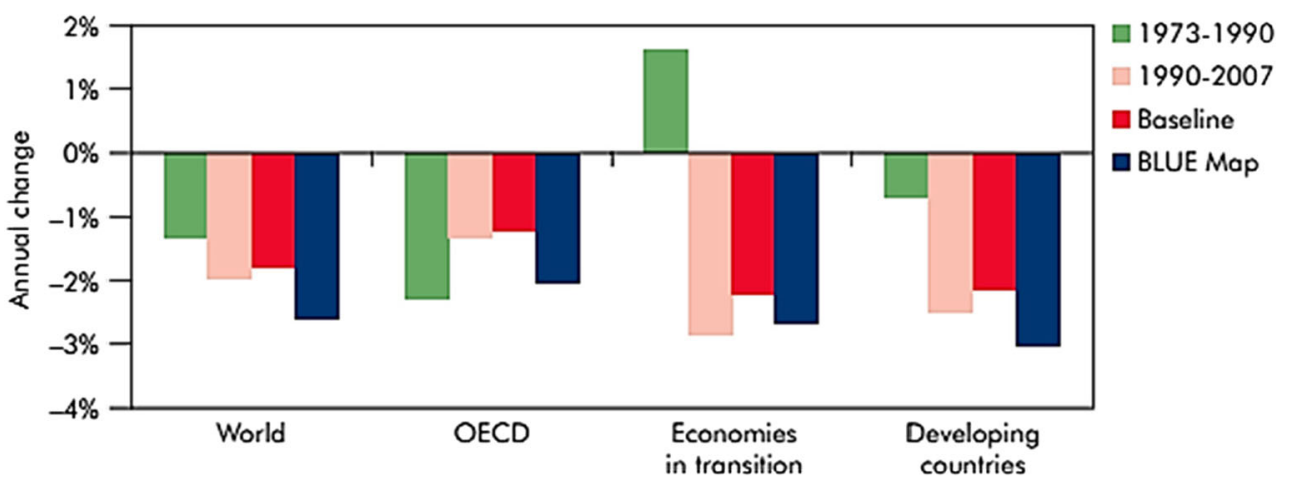

Colorado, Yellow, Ganges and Nile do not reach the ocean in dry seasons. Habitat destruction has contributed to species vanishing at rates of about a thousand times faster than normal. Over $50 \%$ of the agricultural land in drier regions suffers from some degree of deterioration and desertification problems. As available ore grades for some minerals decrease, the amounts of materials that should be mined and processed to produce equivalent product increases, along with the environmental impacts. Bio-accumulative, persistent and toxic chemicals can now be found throughout the food chain. Between 1970 and 2004, worldwide greenhouse gas emissions increased by $70 \%$. Most of the detected increase is in global average temperatures due to the increase in greenhouse gas concentrations associated with anthropogenic

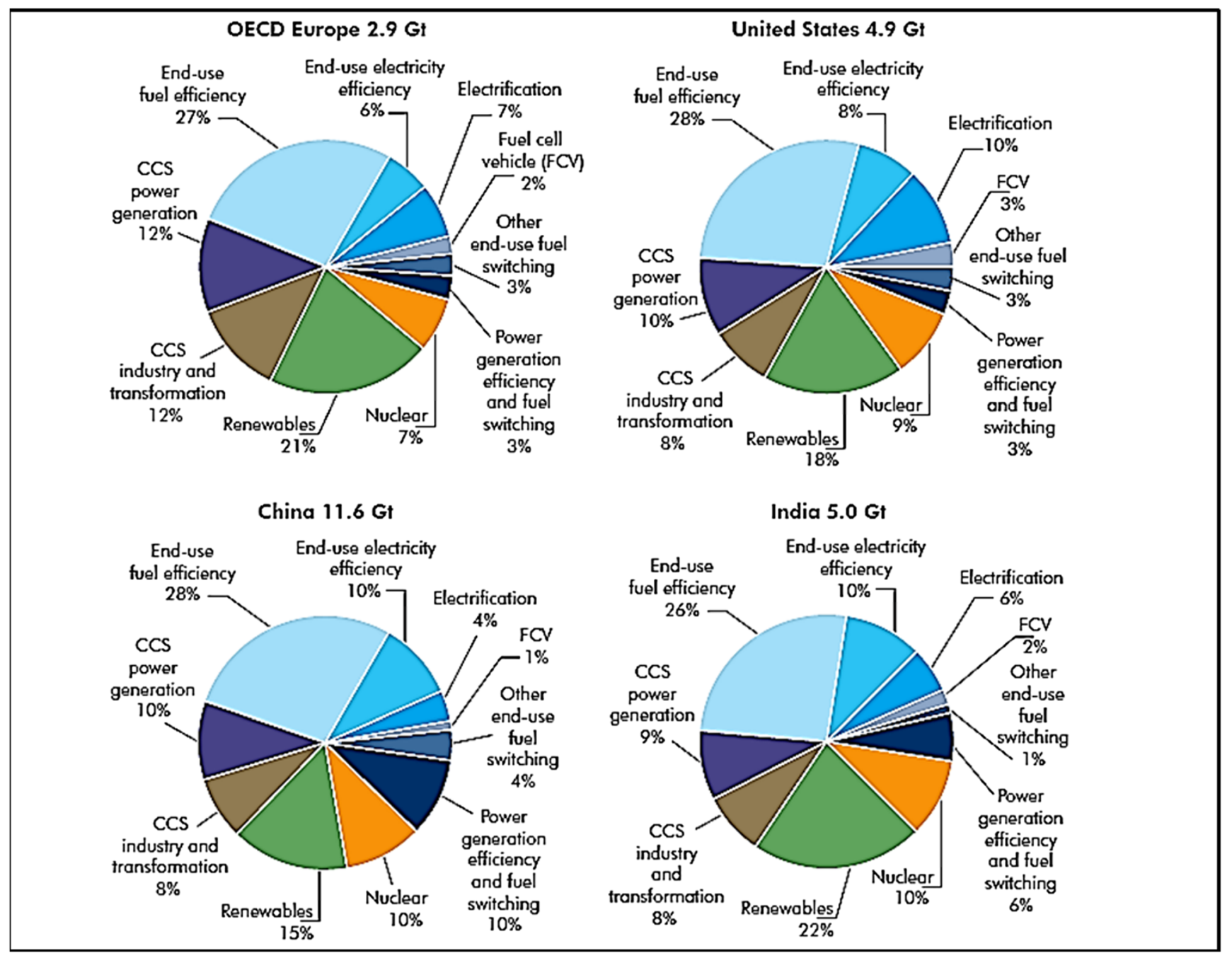

Fig. 3 Contribution of technologies to $\mathrm{CO}_{2}$ emissions abatement in the BLUE Map scenario for different countries and regions, 2050. Source: Energy technology perspectives (IEA) (2010) 
Table 1 Environmental impacts associated with energy consumption that can be improved through life cycle assessment studies are given in tabular form

\begin{tabular}{ll}
\hline Combustion & Oxides of nitrogen and sulphur \\
Fossil fuel & Carbon dioxide (global warming) \\
Photochemical reactions & Converts nitrogen and sulphur to ground level ozone and acid rain. \\
Solar panel & Creation of metal wastes and intensive energy use of heavy metals \\
Renewable fuel & Wood - widespread deforestation \\
Nuclear & Nuclear fuel spent disposal, mining of uranium \\
Hydropower & Land exploitation, alteration in flow patterns of groundwater and \\
& surface water, habitat destruction \\
\hline
\end{tabular}

sources, including the extraction, processing, use and disposal of materials since the mid-twentieth century (UNEP Reports 2016). Therefore, proper material management is necessary (Table 2).

\section{Water}

The availability of clean freshwater suitable for drinking, agriculture and industrial uses is reducing day by day.
Approximately $1000 \mathrm{gal} /$ person/day is the water usage in developed countries. Sometimes, the water is not renewed or replaced at the same rate that it is withdrawn. This will lead to scarcity of clean freshwater. The demand for freshwater in the agricultural sector is high. In the USA, about $49 \%$ of total freshwater usage accounts for agriculture; among this, about $80 \%$ is used for irrigation. About $85-$ $90 \%$ of all freshwater usage is for agriculture in Asia and Africa. By 2025, the water requirements will increase by

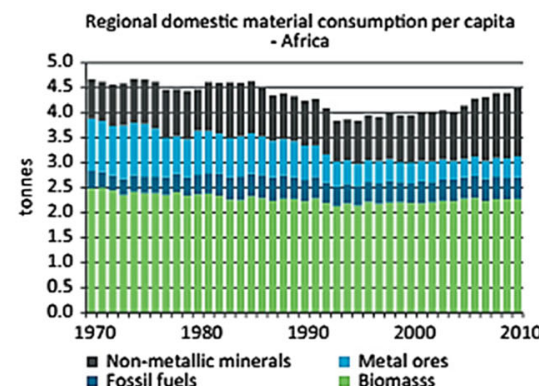

Fossil fuels

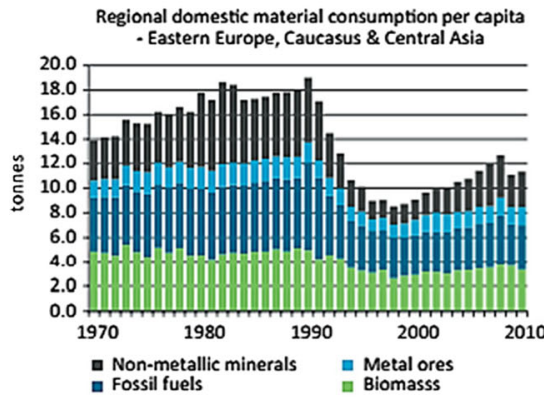

Regional domestic material consumption per capita

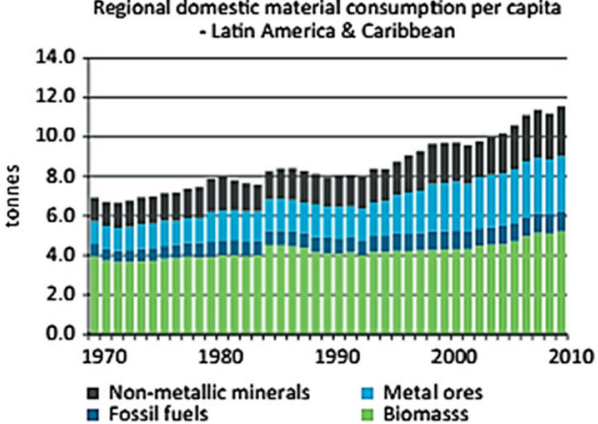

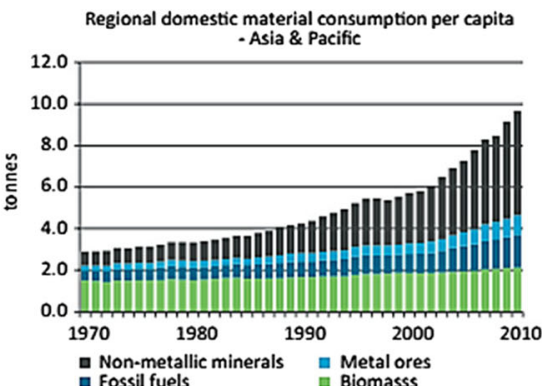

- Non-metallic minerals
Gossil fuels Metal ores
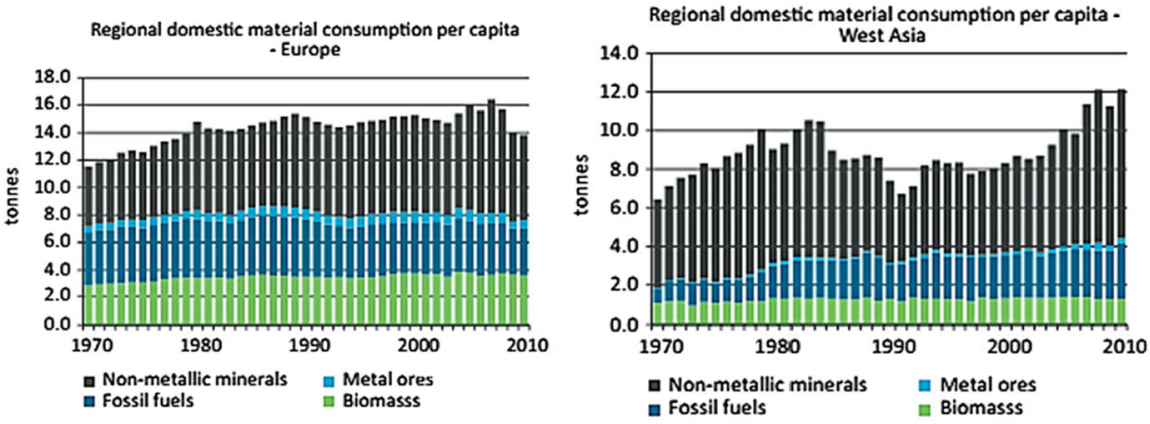

Regional domestic material consumption per capita - North America

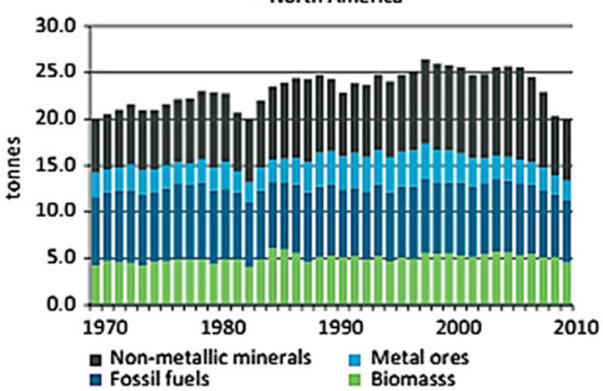

Fig. 4 Per capita domestic material consumption (DMC) by region, 1970-2010, million tonnes. Source: Global Material Flows and Resource Productivity Assessment Report for the UNEP International Resource Panel (2016) 
Table 2 Key approaches to reduce environmental impacts in individual stages

\begin{tabular}{lcc}
\hline $\begin{array}{l}\text { Sustainable materials } \\
\text { management }\end{array}$ & $\begin{array}{c}\text { Sustainable resource } \\
\text { management }\end{array}$ & $\begin{array}{c}\text { Sustainable production } \\
\text { and consumption }\end{array}$ \\
3Rs, Reduce Reuse Recycle & $\begin{array}{c}\text { Design for the Environment } \\
\text { (EPA and Others) }\end{array}$ & $\begin{array}{c}\text { Sustainable Supply-Chain } \\
\text { Management }\end{array}$ \\
$\begin{array}{l}\text { Green chemistry } \\
\text { Eco-labelling }\end{array}$ & Gean Manufacturing & Green procurement \\
\hline
\end{tabular}

1.3 times in agriculture, 1.5 times by industry and 1.8 times by domestic consumption, and the world's irrigation areas are expected to reach about 330 million hectares. The global freshwater withdrawals account for 20\%; and among this, 57-69\% is for nuclear and hydropower generation, $0.5-3 \%$ is for thermal power generation and $30-40 \%$ is for industrial processes (Shiklomanov 1999; World Commission on Water 1999). For electrical power generation and irrigation, a large amount of freshwater is stored in dams and reservoirs in the industrial sector. Estimation shows that the evaporated water volume from reservoirs exceeds the collective freshwater needs of domestic consumption and industry. In tropical regions, it mainly contributes to water losses (UNESCO 1999).

In developed countries, the average person uses about 500$800 \mathrm{l} /$ day $\left(300 \mathrm{~m}^{3} /\right.$ year), while in developing countries it is about $60-150 \mathrm{l} / \mathrm{day}\left(20 \mathrm{~m}^{3} /\right.$ year $)$. This estimate indicates that average consumption of people in developed countries is about 10 times more than that in developing countries (UNESCO 2000). In developing countries, the supply of safe drinking water and sanitation are the major issues. These are mainly due to illegal connections and vandalism, leakages, squandering of precious water, etc. (UNCSD 1999). The human cost may be affected directly or indirectly due to these failings by widespread health problems, excessive labour usage and women being forced to obtain water from long distances by travelling for their families (Gleick 1995). Improvement in facilities of water and sanitation brings poverty alleviation as well as economic and social development (WHO/UNICEF 2000). Eighty per cent of diseases in developing countries is due to the lack of access to clean potable water. Pathogens spread through water and kill 25 million people every year by amoeba-linked cholera, diarrhoea and typhoid. Approximately 3900 children die every day (WHO 2004). Ninety per cent of 2.2 million deaths of children are under 5 years. Each year, more than five million people die from water-related diseases. A child dies from a disease related to water every $15 \mathrm{~s}$. Thirty per cent of water-related deaths are due to diarrhoea. Eightyfour per cent of water-related deaths are in children aged up to 14 years, and $98 \%$ of water-related deaths occur in the developing world. The most effective management for this type of intervention is providing safe drinking water
Table 3 Water consumption in major cities

\begin{tabular}{lll}
\hline Place & Population & Domestic water usage \\
\hline Mexico City, Mexico & 21 million people & $3641 /$ person/day \\
Buenos Aires, Argentina & 12 million people & $378-4001 /$ person/day \\
Shanghai, China & 23 million inhabitants & 411 1/person/day \\
New Delhi, India & 20 million inhabitants & $781 /$ person/day (Shaban 2008) \\
\hline
\end{tabular}

Fig. 5 Virtual water loss (food waste is water waste). Source: The United Nations Food and Agriculture Organization

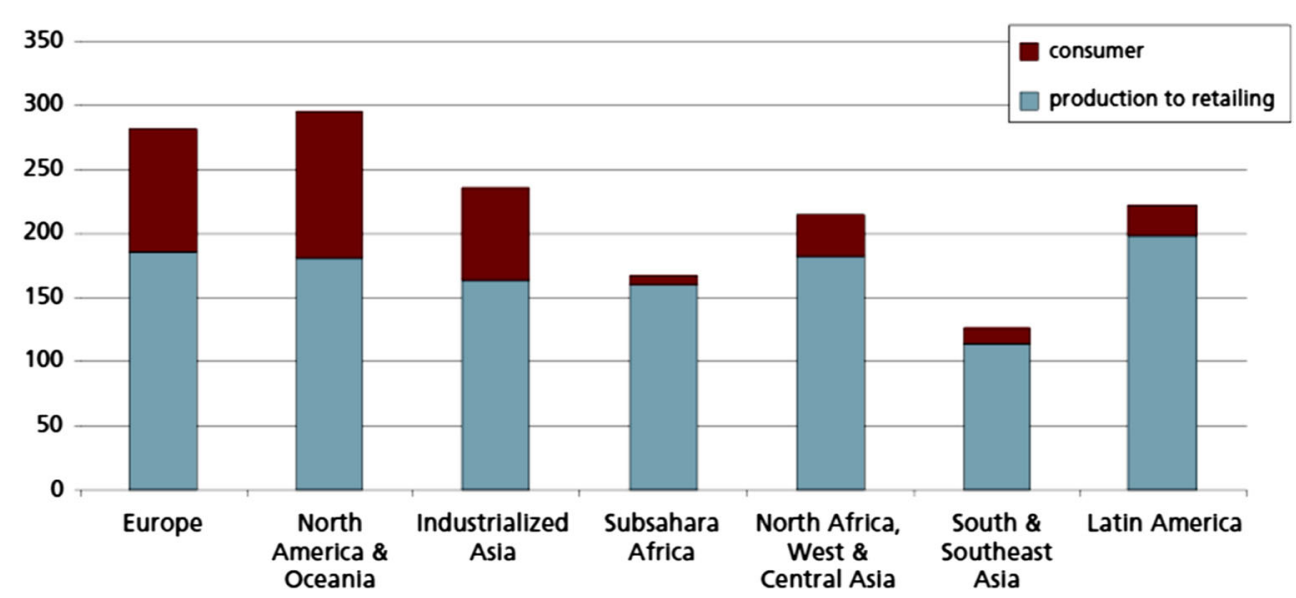


Table 4 Water usage for energy production

$$
\begin{aligned}
& \text { Natural gas — } 3 \text { gal/million BTU } \\
& \text { Hydroelectric — } 20 \text { gal/million BTU } \\
& \text { Liquid natural gas_-145 } \\
& \text { gal/million BTU }
\end{aligned}
$$

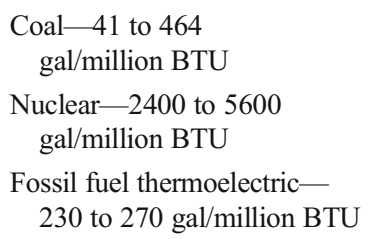

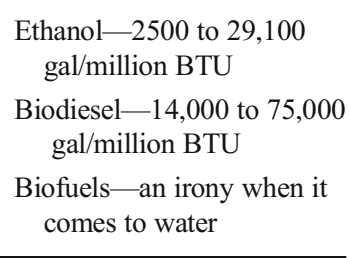

and proper disposal of human waste. Agriculture consumes the largest share of freshwater. The industry is a major consumer in North America and Europe. Booming economies (China, India, Brazil) will influence the ratio of freshwater. Water consumption in major cities is shown in Table 3. Urbanisation of world is growing in a rapid manner and about $70 \%$ of the world's population will live in urban areas. In developing countries, cities grow by an increase of 5 million residents every month. Expansion of slums and the infrastructure does not keep up with the pace of expansion. This will result in lack of access to safe drinking water and adequate sanitation (United Nations, Department of Economic and Social Affairs, Population Division 2014). Through waste of food virtual water (water embedded in food products), water loss will happen (Fig. 5) (Hoekstra and Chapagain 2008). Energy production (electricity) is one of the largest users of water Table 4. For example, for a $60-\mathrm{W}$ incandescent bulb for $12 \mathrm{~h}$ a day for a year in 111 million houses, the power plant would consume about 655 billion gallons of water. Electricity consumes $20 \%$ of water excluding agriculture. Hydraulic fracturing is also another problem which causes water depletion. Natural gas is projected to increase by $30 \%$ over the next 25 years. Since the 1940s, over one million wells have already been hydraulically fractured. Around 35,000 wells are fractured every year. Hydraulic fracturing uses a mix of chemical additives, sand and water (Virginia Tech Study, study report 2008). Therefore, natural water resource usage should be in a scientific manner, otherwise the resources get depleted and become inappropriate to access for the future generations.

\section{Conclusions}

For our planet to survive, a sustainable world is necessary. It is one of the most challenging goals for developing as well as for developed countries in the world, because the way to follow sustainability is different for developing countries than for developed ones. To build a more sustainable environment includes changes to economic, social and environmental factors. As per the discussions, the demand for energy, material and water is increasing day by day. The developing countries are more exposed to survival problems especially in the fields of lifestyle, food, shelter, health and education. They are trying to gain the economic conditions by overexploitation of resources and no importance is given to sustainability, which will also affect the developed world in the future. Therefore, sustainable development policies are necessary for these developing countries, and for developing sustainable policies, the life cycle thinking is a better approach.

\section{References}

Alam O (2016) Life cycle assessment problems and prospects in Bangladesh: a case study of healthcare waste management of Chittagong metropolitan city in Life Cycle Assessment and Other Assessment Tools for Waste Management and Resource Optimization, http://dc.engconfintl.org/lca_waste/51

Archana D, Sohini G (2015) Indian Conference on Life Cycle Management (ILCM). Int J Life Cycle Assess. https://doi.org/10. 1007/s11367-015-0882-y (Conference Announcement)

Burtland GH (1987) Our common future: the World Commission on Environment and Development. Available: http://www.undocuments.net/wced-ocf.htm

Ehrlich PR, Holdren JP (1971) Impact of population growth. Science, new series 171(3977):1212-1217

ElkingtonJ (1997) "Cannibals with forks: the triplebottom line of 21st century business". Capstone Publishing Ltd, Oxford

Energy technology perspectives guide - (International Energy Agency) (2010) Available: https://www.iea.org/publications/ freepublications/publication/etp2010.pdf

Gleick PH (1995) Human population and water: to the limits in the 21st century. American Association for the Advancement of Science Symposium: Human Population and Water, Fisheries, and Coastal Areas: Science and Policy ssues. Washington, D.C.

Global water supply and sanitation assessment 2000 report (2000) Geneva: World Health Organization, Water Supply and Sanitation Collaborative Council, United Nations Childrens Fund

Hoekstra AY, Chapagain AK (2008) Globalization of water: sharing the planet's freshwater resources. Blackwell Publishing, Oxford

Shaban A, (2008) Water poverty in urban India: a study of major cities Tata Institute of Social Science, Mumbai Seminar Paper UGCSummer Programme

Shiklomanov (1999) World water resources and their use. Database on CD Rom. UNESCO, Paris

UNCSD United Nations Commission on Sustainable Development (1999) Comprehensive review of changing consumption and production patterns: report of the Secretary-General, United Nations Commission on Sustainable Development, Seventh Session 19-30 April 1999, United Nations, New York

UNEP Reports (2016) UNEP International resource panel 
UNESCO (1999) Summary of the Monograph 'World Water Resources at the beginning of the 21st century', prepared in the framework of IHP UNESCO

UNESCO (2000) Water use in the world: present situation/future needs United Nations, Department of Economic and Social Affairs, Population Division (2014) World urbanization prospects: the 2014 revision, highlights (ST/ESA/SER.A/352)
Virginia Tech Study, study report (2008) Tamim Younos, Rachelle Hill and Heather Poole, Water use efficiency of energy production and power generation technologies

WHO (2004) World Health Organisation report

World Commission on Water (1999) World's rivers in crisis-some are dying; others could die. World Water Council 